\title{
Students Integrated Science Achievement as Predictor of Later Achievement in Biology in Selected Government Secondary Schools in Soba Local Government Area, Kaduna State, Nigeria
}

\author{
Dike, Ngozi I. And Garba, Maryam A. \\ Department Of Biology, School Of Science, Federal College Of Education, Zaria, Kaduna State, Nigeria
}

\begin{abstract}
This article examines the academic achievement of students in Integrated Science at Junior Secondary School (JSS) as a predictor of their later achievement in Biology at the Senior Secondary School (SSS) in Soba, Kaduna State, Nigeria. Random sampling technique was used to select 5 senior secondary schools from the 10 government senior secondary schools in the study area. The sample comprised of 842 students selected from 1013 students. The study adopts the survey design. The only instrument for the study was the documentary source where the results of both the Junior Secondary Certificate Examination (JSCE) and Senior Secondary Certificate Examination (SSCE) were obtained from each of the selected schools. The instrument was considered to be standard, valid and reliable. The research questions were answered by the statistical mean while the hypotheses were analyzed using the chi-square and cross tabulation statistics. The findings of the study revealed that achievement of students in Integrated Science significantly predict their later achievement in Biology at SSCE irrespective of their gender. It was recommended among others that career counselors should consult students' past record in Integrated Science before advising them to offer science subjects including Biology.
\end{abstract}

Keywords: Integrated science, biology, predictive validity, academic achievement

\section{Introduction}

Predictive validity of different examinations on a future academic achievement facilitates admission decisions and enhances educational services at educational institutions across the globe. These include the predictive validity of primary school examinations used on future academic performance in post primary schools; predictive validity of junior secondary school examinations on performance in senior secondary school and predictive value of senior secondary school examinations or university matriculation examinations (UME) on the performance at the tertiary level.

Different input variables or predictor variables are used in determining the predictive validity of these examinations. One of the most important methods of evaluating student persistence is through academic achievement measured by grade point average (GPA) (McGrath and Braunstein, 1997). Others particularly those involving models tend to involve more input variables. Huang and Fang (2013) for instance, developed and compared four types of mathematical models to predict student academic performance in engineering dynamics; the input variables of the models include GPA, grade earned in four pre-requisite courses and scores on three dynamic mid-term examinations. Chen et al (2014) used previous examination results and other factors such as the location of the student's high school and gender as well as other input variables to predict the student academic performance based on the artificial neural network (ANN) with two meta-heuristic algorithms.

Most literature on predictive validity of different examinations on future academic achievement of students however tends to focus mainly on their pre-entry and post scores. Adebola (2004) carried out a study on the predictive validity of JSS Mathematics, SSS Mathematics, Physics and Further Mathematics and reported a positive relationship between performance in JSS Mathematics and performance in SSS Mathematics, Physics and Further Mathematics. In relation to gender differences, the study further revealed that while there is no significant gender difference in students' performance in JSS mathematics, their performance in SSS Mathematics is significant in favour of the boys. Ademola (2004) studied students' performance in Mathematics as correlates of their performance in other basic science subjects - Biology, Chemistry, Physics and Agricultural Science and found a low positive correlation between JSS Mathematics and SSS Biology, Chemistry, Physics and Agricultural Science; however Chemistry appeared to be the best predictor of performance in Mathematics. Falaye and Afolabi (2005) studied the predictive validity of Osun state Junior Secondary Certificate Examination (JSCE) in the academic performance of the students and reported that the overall performance in JSCE tend to have low capacity to predict performance in SSCE. Omirin and Ale (2008) investigated the predictive validity of English and Mathematics Mock results of students on West African School Certificate 
Examination (WASCE) in Ekiti State, Nigeria and reported that Mock English and Mathematics scores helped significantly in predicting the success in academic performance of students in WASCE; the findings further revealed that English Mock results were better predictor of success in WASCE than Mathematics. Dike (2001) conducted a study on students' SSCE Grades as correlate of their academic performance in science in the National Certificate of Education at the Federal College of Education, Zaria and found non-significant correlation between students' SSCE grades and their performance in Biology, Chemistry and Physics at the NCE level. Abdullahi (1983) conducted a study on the predictive validity of UME on first year university examination (FUE) at University of Ilorin, Kwara State, Nigerian in Biology, Chemistry, Physics, Economics and Geography and found a significant correlation between UME and FUE scores in Chemistry, Physics and Economics but low correlation in Biology and Geography. Nwanza (1993) carried out an investigation on the predictive validity of Malawi School Certificate Examination (MSCE) for selection of candidates into the University of Malawi and reported that MSCE grades are reasonable predictors of academic success in the first year of the university.

Integrated Science in the JSS which is the focus of this study is a subject that occupies an important place in science education programme in Nigerian. One of the major objectives of Integrated Science curriculum is to lay a solid foundation for subsequent specialized study in these science subjects including Biology at SSS. Researchers on Integrated Science as a predictor of achievement in science subjects have had divergent findings. Oyedokun (1998) reported that students' scores in Integrated Science predicted their later achievement in Biology in Kontagora, Niger State, Nigeria. Osokoya (1999), Olatoye and Afuwape (2004) reported from their separate studies that students' scores in Integrated Science not only predicted their later achievements in Biology but also in Chemistry and Physics. On the other hand, Edokpayi and Suleiman (2011) found that the academic achievement of students in JSCE among some selected schools in Zaria metropolis, Kaduna state, Nigeria, was a poor predictor of their later achievement in Chemistry. Afolabi and Adewolu (1998) and Adebayo (2012) also reported in their separate studies that students' JSCE achievement is a poor predictor of their achievement at SSCE in Ekiti and Osun states, Nigeria, respectively.

\section{Objective Of The Study}

The objective of the study is specifically to find out the predictive strength of JSCE achievement of students in Integrated Science in predicting their achievement in Biology at the SSCE in Soba LGA, Kaduna state, Nigeria.

\section{Statement of the Problem}

Integrated Science is the bedrock on which the science subjects - Biology, Chemistry and Physics at the Senior Secondary Schools is laid. Emphasis is therefore placed on it to provide the students with the right foundation for higher achievements in these science subjects at the SSCE. It has however been observed that there is a persistent poor performance of students particularly in SSCE over the years. This poor performance of students has been a matter of concern for all stakeholders including government, law makers, teachers, parents and even the public at large. Several factors have been attributed to the poor performance such as inadequate facilities, poor attitude of students to work, inadequate teaching methods to mention but a few. Achievements of students in Integrated Science at JSCE which is the basis of their placement in the senior secondary schools have also been implicated as a factor for the poor achievement of students in science subjects including Biology. However little researches have been done on it which revealed divergent findings and this underlies the importance of this study.

\section{Research Questions}

The following research questions become imperative:

- To what extent do the students' academic achievements in Integrated Science at JSCE predict their achievements in Biology at SSCE?

- To what extent do the male students' academic achievements in Integrated Science at JSCE predict their SSCE achievements in Biology?

- To what extent do the female students' achievements in Integrated Science at JSCE predict their SSCE achievements in Biology?

- Is there any significant difference between male and female students' academic achievements in Integrated Science at JSCE?

- Is there any significant difference between male and female students' achievements in Biology at SSCE?

Hypotheses

- There is no significant relationship between students' academic achievements in Integrated Science at JSCE and in Biology at SSCE.

- There is no significant relationship between the male students' academic achievements in Integrated Science at JSCE and their SSCE achievements in Biology. 
- There is no significant relationship between the female students' academic achievements in Integrated science at JSCE and their SSCE achievements in Biology.

- There is no significant difference between the male and female students' academic achievements in Integrated Science at JSCE.

- There is no significant difference between the male and female students' academic achievements in Biology at SSCE.

\section{Methodology}

The study adopted an ex-post facto research design in which both the dependent and independent variables have already occurred and the researchers cannot manipulate them.

Population and Sampling Technique

The population of this study includes the ten government senior secondary schools in Soba LGA, Kaduna state, Nigeria. A sample of five senior secondary schools was selected by simple random sampling technique from the total population. Those in the selected senior secondary schools comprised of 1013 who had passed through JSCE between the years 2011/2012-2014/2015 and out of the number, 842 students (494 males and 348 females) were selected.

\section{Instrument/Data Collection}

Documentary source was the only instrument used for this study. The results are already standardized by external examining bodies and therefore were valid and reliable. The results of both the JSCE and SSCE were collected from the principals/examination officers of each of the selected schools and were recorded accordingly. The score of each student in Integrated Science was matched with his/her score in Biology. The genders of the students were also obtained. The students' numbers were coded $M_{i}-M_{n}$ and $F_{1}-F_{n}($ where $M=$ male students and $\mathrm{F}=$ female students and $\mathrm{n}=$ the total number of male and female students in line with their scores in Integrated Science and Biology achievements.

Data Analysis

The scores of JSCE achievements of students were correlated with their scores of SSCE achievements using the chi-square and its cross tabulation statistics, while the t-test statistics was used in the comparison of the male and female students' achievement in JSCE and SSCE. Each item is presented on a table for clarity of purpose.

Question 1:

\section{Results}

To what extent do students' academic achievements in Integrated Science at JSCE predict their achievements in Biology at SSCE?

Hypothesis I:

There is no significant relationship between students' academic achievements in Integrated Science at JSCE and in Biology at SSCE.

Table 1: JSCE grade/SSCE grade cross tabulation 


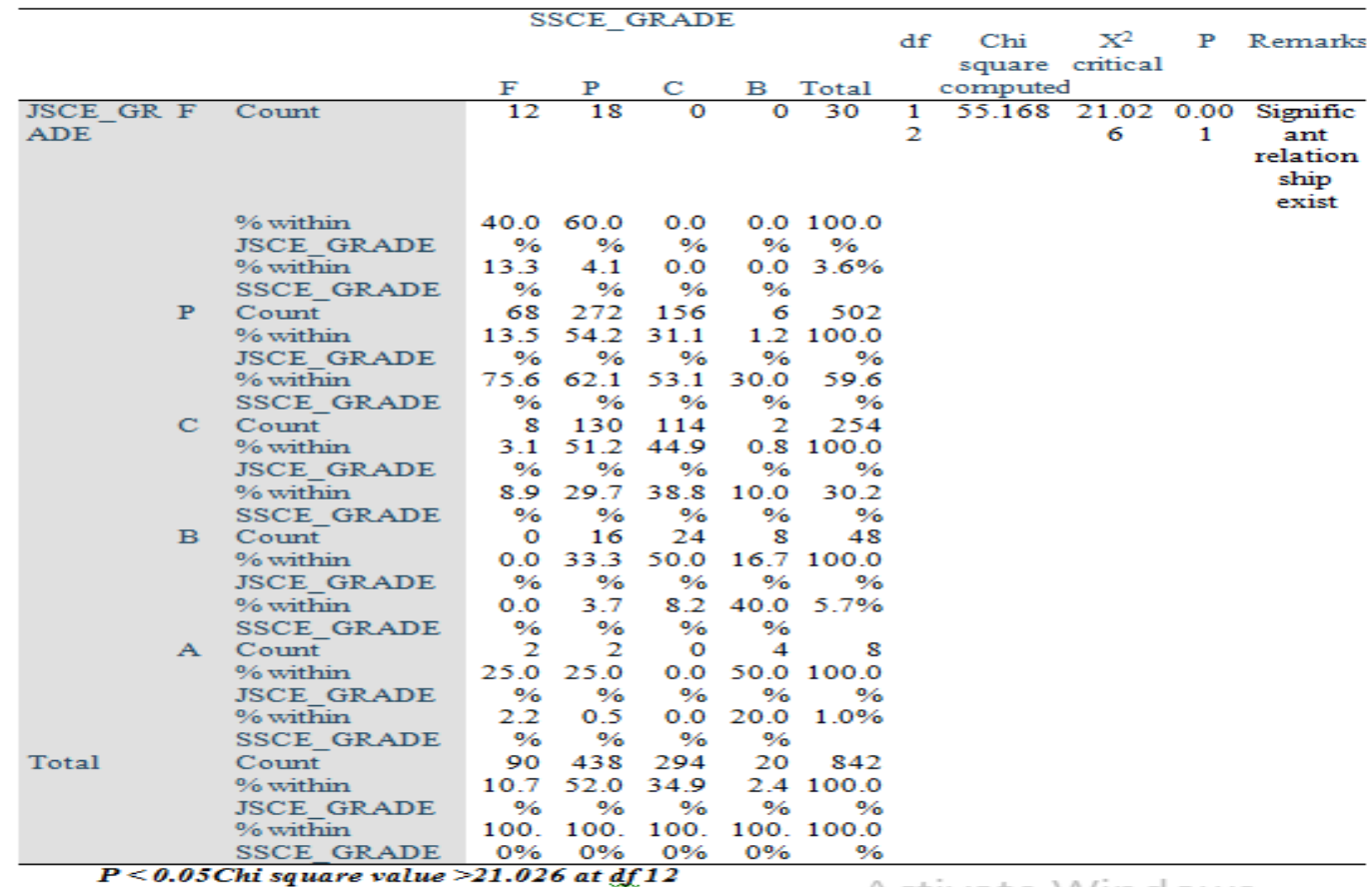

Table 1 reveals that the calculated $\mathrm{P}$ value of 0.001 is lower than the 0.05 alpha level of significance and the chi square computed value of 55.168 was higher than the critical chi square value of 21.026. Therefore, the null hypothesis which states that there is no significant relationship between students' academic achievements in Integrated Science at JSCE and Biology at SSCE is hereby rejected. Students' achievements in Integrated Science significantly predict their achievements in Biology. This shows that the higher the students' grades in JSCE, the higher their scores in SSCE which means that a student who achieves well in Integrated Science is likely to also achieve well in Biology.

To buttress this, the cross tabulation statistics (Table 1) also showed that among the 30 students that failed in JSCE, 12 also failed in SSCE while 18 managed to score P grade. Among the 502 of them that had P in JSCE, 272 also had P in SSCE, 68 failed, 156 scored C while only 6 scored B. Among the 254 of them that had $\mathrm{C}$ grade in JSCE, 114 also scored C in SSCE, 130 scored P, 2 scored B while only 8 failed. Among the 48 that had B grade in JSCE, 8 scored B in SSCE, 24 scored C, 16 scored P and none failed. Among the 8 of them that had A grade in JSCE, none had A in SSCE but 4 scored B, none scored C, while 2 each scored P and failed respectively.

Question 2

To what extent do the male students' academic achievements in Integrated Science at JSCE predict their SSCE achievements in Biology?

Hypothesis 2

There is no significant relationship between the male students' academic achievements in Integrated Science at JSCE and their SSCE achievements in Biology.

Table 2: Chi square and cross tabulation statistics on relationship between JSCE GRADE and SSCE GRADE 


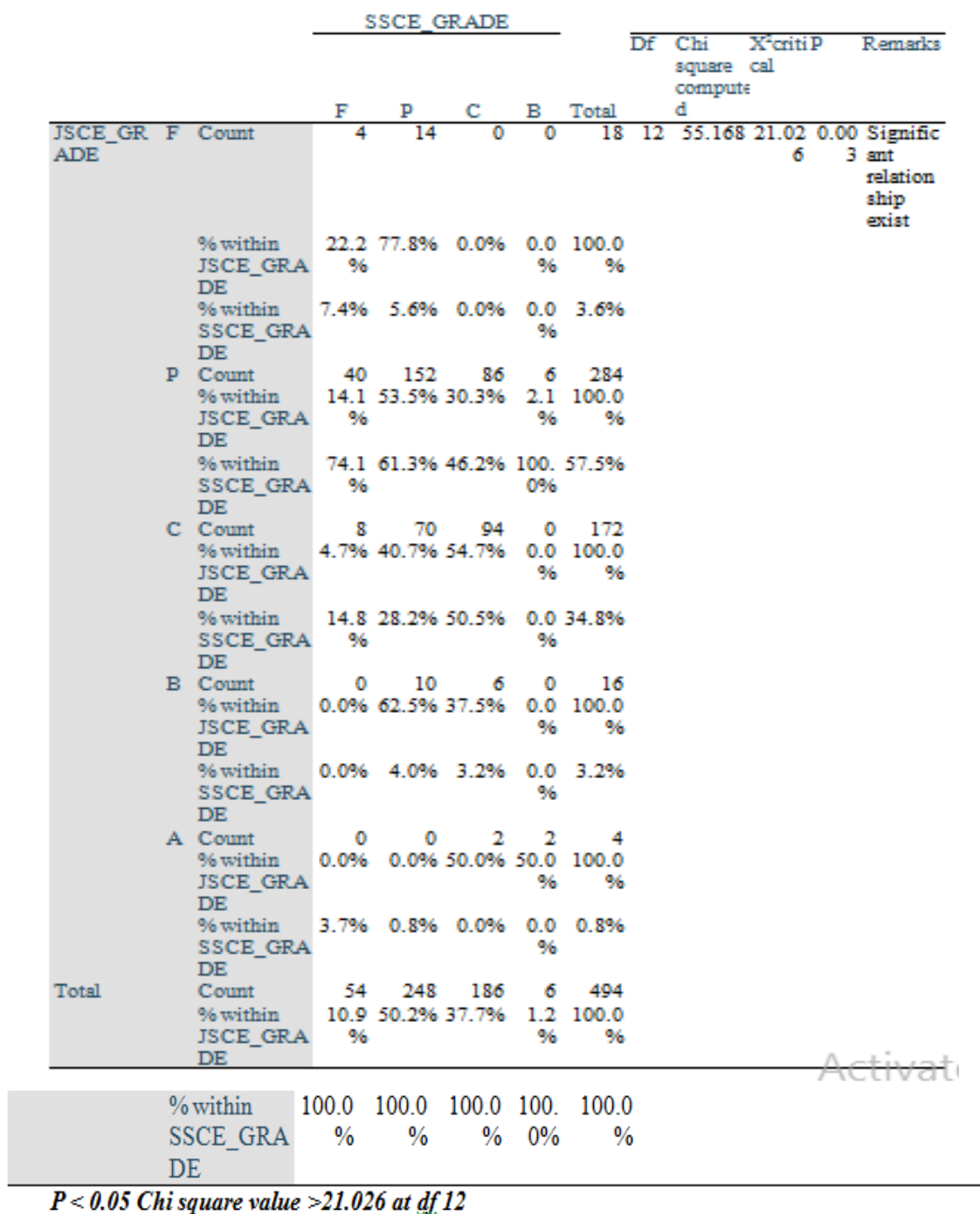


Table 2 shows that the calculated $\mathrm{P}$ value of 0.003 is lower than the 0.05 alpha level of significance and the chi-square computed value of 55.168 was higher than the critical chi-square value of 21.026. Therefore, the null hypothesis which states that there is no significant relationship between the male students' academic

SSCE_GRADE | Tot

achievements in Integrated Science at JSCE and their SSCE achievements in Biology is hereby rejected. The male students' academic achievements in Integrated Science significantly predict their achievements in Biology. This means that a male student who achieves well in Integrated Science is likely to also achieve well in Biology.

Table 2 shows further that among the 18 male students that failed in JSCE, 4 also failed in SSCE while 14 managed to score P grade; among the 284 of them that had P at JSCE, 152 also scored P in SSCE, 86 had C, 6 had B while 40 failed. Among the 173 that scored C in the JSCE, 94 also had C, 70 had P, none had B, while 8 failed in the SSCE. Among the 16 that scored B in JSCE, none of them had B or failed in SSCE but 6 had C and 10 had P; among the 4 that scored A grade in JSCE, none of them had A, C, or failed but 2 each had B and C respectively.

\section{Question 3}

To what extent do the female students' academic achievements in Integrated Science at JSCE predict their SSCE achievements in Biology?

Hypothesis 3

There is no significant relationship between the female students' academic achievements in Integrated Science at JSCE and their SSCE achievements in Biology.

Table 3: JSCE_GRADE * SSCE_GRADE Cross tabulation

$P<0.05$, Chi square value of $215.34>21.026$ at df 12 


\begin{tabular}{|c|c|c|c|c|c|c|c|c|c|c|c|c|}
\hline & & & $\mathrm{F}$ & $P$ & $\mathrm{C}$ & B & & Df & $\begin{array}{l}\text { X2 } \\
\text { compu } \\
\text { d }\end{array}$ & $\begin{array}{l}\mathrm{X} 2 \\
\text { critic } \\
\text { al }\end{array}$ & $P$ & $\begin{array}{l}\text { Remark } \\
\mathrm{s}\end{array}$ \\
\hline \multirow[t]{15}{*}{$\begin{array}{l}\text { JSCE } \\
\text { _GR } \\
\text { ADE }\end{array}$} & \multirow[t]{3}{*}{$\mathrm{F}$} & Count & 8 & 4 & 0 & 0 & 12 & 12 & $\begin{array}{r}215.3 \\
43\end{array}$ & $\begin{array}{r}21.0 \\
26\end{array}$ & $\begin{array}{r}0.0 \\
2\end{array}$ & $\begin{array}{l}\text { Signifi } \\
\text { cant } \\
\text { relation } \\
\text { ship } \\
\text { exist }\end{array}$ \\
\hline & & $\begin{array}{l}\% \text { within } \\
\text { JSCE_GRADE }\end{array}$ & $\begin{array}{r}66.7 \\
\%\end{array}$ & $\begin{array}{r}33.3 \\
\%\end{array}$ & $\begin{array}{r}0.0 \\
\%\end{array}$ & $\begin{array}{r}0.0 \\
\%\end{array}$ & $\begin{array}{r}100 \\
.0 \\
\%\end{array}$ & & & & & \\
\hline & & $\begin{array}{l}\% \text { within } \\
\text { SSCE_GRADE }\end{array}$ & $\begin{array}{r}22.2 \\
\%\end{array}$ & $\begin{array}{r}2.1 \\
\%\end{array}$ & $\begin{array}{r}0.0 \\
\%\end{array}$ & $\begin{array}{r}0.0 \\
\%\end{array}$ & $\begin{array}{r}3.4 \\
\%\end{array}$ & & & & & \\
\hline & \multirow[t]{3}{*}{$\mathrm{P}$} & Count & 28 & 120 & 70 & 0 & 218 & & & & & \\
\hline & & $\begin{array}{l}\% \text { within } \\
\text { JSCE_GRADE }\end{array}$ & $\begin{array}{r}12.8 \\
\%\end{array}$ & $\begin{array}{r}55.0 \\
\%\end{array}$ & $\begin{array}{r}32.1 \\
\%\end{array}$ & $\begin{array}{r}0.0 \\
\%\end{array}$ & $\begin{array}{r}100 \\
.0 \\
\%\end{array}$ & & & & & \\
\hline & & $\begin{array}{l}\% \text { within } \\
\text { SSCE_GRADE }\end{array}$ & $\begin{array}{r}77.8 \\
\%\end{array}$ & $\begin{array}{r}63.2 \\
\%\end{array}$ & $\begin{array}{r}64.8 \\
\%\end{array}$ & $\begin{array}{r}0.0 \\
\%\end{array}$ & $\begin{array}{l}62 . \\
6 \%\end{array}$ & & & & & \\
\hline & \multirow[t]{3}{*}{$\mathrm{C}$} & Count & 0 & 60 & 20 & 2 & 82 & & & & & \\
\hline & & $\begin{array}{l}\% \text { within } \\
\text { JSCE_GRADE }\end{array}$ & $\begin{array}{r}0.0 \\
\%\end{array}$ & $\begin{array}{r}73.2 \\
\%\end{array}$ & $\begin{array}{r}24.4 \\
\%\end{array}$ & $\begin{array}{r}2.4 \\
\%\end{array}$ & $\begin{array}{r}100 \\
.0 \\
\%\end{array}$ & & & & & \\
\hline & & $\begin{array}{l}\% \text { within } \\
\text { SSCE_GRADE }\end{array}$ & $\begin{array}{r}0.0 \\
\% \\
\end{array}$ & $\begin{array}{r}31.6 \\
\% \\
\end{array}$ & $\begin{array}{r}18.5 \\
\%\end{array}$ & $\begin{array}{r}14.3 \\
\% \\
\end{array}$ & $\begin{array}{l}23 . \\
6 \%\end{array}$ & & & & & \\
\hline & \multirow[t]{3}{*}{ B } & Count & 0 & 6 & 18 & 8 & 32 & & & & & \\
\hline & & $\begin{array}{l}\% \text { within } \\
\text { JSCE_GRADE }\end{array}$ & $\begin{array}{r}0.0 \\
\%\end{array}$ & $\begin{array}{r}18.8 \\
\%\end{array}$ & $\begin{array}{r}56.3 \\
\%\end{array}$ & $\begin{array}{r}25.0 \\
\%\end{array}$ & $\begin{array}{r}100 \\
.0 \\
\% \\
\end{array}$ & & & & & \\
\hline & & $\begin{array}{l}\% \text { within } \\
\text { SSCE_GRADE }\end{array}$ & $\begin{array}{r}0.0 \\
\%\end{array}$ & $\begin{array}{r}3.2 \\
\%\end{array}$ & $\begin{array}{r}16.7 \\
\%\end{array}$ & $\begin{array}{r}57.1 \\
\%\end{array}$ & $\begin{array}{r}9.2 \\
\%\end{array}$ & & & & & \\
\hline & \multirow[t]{3}{*}{ A } & Count & 0 & 0 & 0 & 4 & 4 & & & & & \\
\hline & & $\begin{array}{l}\% \text { within } \\
\text { JSCE_GRADE }\end{array}$ & $\begin{array}{r}0.0 \\
\%\end{array}$ & $\begin{array}{r}0.0 \\
\%\end{array}$ & $\begin{array}{r}0.0 \\
\%\end{array}$ & $\begin{array}{r}100 . \\
0 \%\end{array}$ & $\begin{array}{r}100 \\
.0 \\
\%\end{array}$ & & & & & \\
\hline & & $\begin{array}{l}\text { \% within } \\
\text { SSCE_GRADE }\end{array}$ & $\begin{array}{r}0.0 \\
\%\end{array}$ & $\begin{array}{r}0.0 \\
\%\end{array}$ & $\begin{array}{r}0.0 \\
\%\end{array}$ & $\begin{array}{r}28.6 \\
\%\end{array}$ & $\begin{array}{r}1.1 \\
\%\end{array}$ & & & & & \\
\hline \multirow{3}{*}{\multicolumn{2}{|c|}{ Total }} & Count & 36 & 190 & 108 & 14 & 348 & & & & & \\
\hline & & $\begin{array}{l}\% \text { within } \\
\text { JSCE_GRADE }\end{array}$ & $\begin{array}{r}10.3 \\
\%\end{array}$ & $\begin{array}{r}54.6 \\
\%\end{array}$ & $\begin{array}{r}31.0 \\
\%\end{array}$ & $\begin{array}{r}4.0 \\
\%\end{array}$ & $\begin{array}{r}100 \\
.0 \\
\%\end{array}$ & & & & & \\
\hline & & $\begin{array}{l}\% \text { within } \\
\text { SSCE_GRADE }\end{array}$ & $\begin{array}{r}100 . \\
0 \%\end{array}$ & $\begin{array}{r}100 . \\
0 \%\end{array}$ & $\begin{array}{r}100 . \\
0 \%\end{array}$ & $\begin{array}{r}100 . \\
0 \%\end{array}$ & $\begin{array}{r}100 \\
.0 \\
\% \\
\end{array}$ & & & & & \\
\hline
\end{tabular}

Table 3 reveals that the calculated $\mathrm{P}$ value of 0.002 is lower than the 0.05 alpha level of significance and the calculated chi-square value of 215.343 is higher than the critical chi-square value of 21.026. Therefore the null hypothesis which states that there is no significant relationship between the female students' academic achievements in Integrated Science at JSCE and their SSCE achievements in Biology is hereby rejected. The 
female students' academic achievements in Integrated Science significantly predict their achievements in Biology. This implies that a female student who achieves well in integrated science is likely to also achieve well in Biology.

Table 3 further buttresses this by showing that among the 12 female students that failed in JSCE, 8 of them also failed in SSCE while only 4 managed to score P. Among the 218 of them that scored P in JSCE, 120 also had P, 70 had C, none had B and 28 failed in SSCE. Among the 82 that scored C in JSCE, 20 also had C in SSCE, 60 had P, only 3 had B and none failed. Among the 32 that scored B in JSCE, 8 also had B, 18 had C, 6 had $\mathrm{P}$ and none of them failed in SSCE. The table further showed that among the remaining 8 female students, none scored A in both JSCE and SSCE but 4 each scored C and B respectively.

Question 4

Is there any significant difference between male and female students' academic achievements in Integrated Science at JSCE?

Hypothesis 4

There is no significant difference between the male and female students' academic achievements in Integrated Science at JSCE.

Table 4: Independent t-test statistics of the male and female students' academic achievements in Integrated

Science at JSCE

\begin{tabular}{|l|l|l|l|l|l|l|l|l|}
\hline Variable & Gender & N & Mean & Std. dev. & DF & $\begin{array}{l}\text { T. } \\
\text { calculated }\end{array}$ & T. critical & P \\
\hline $\begin{array}{l}\text { JSSCE } \\
\text { PERFORMANCE }\end{array}$ & MALE & 246 & 45.0772 & 7.58436 & 244 & 1.622 & 1.96 & 0.600 \\
\hline & FEMALE & 174 & 46.2874 & 7.51342 & & & & \\
\hline
\end{tabular}

Table 4 reveals that the calculated P-value of 0.600 is higher than 0.05 alpha level of significance and the t-calculated value of 1.622 is lower than the t-critical value of 1.96. Their mean score performance at JSCE are 48.08 and 46.29 for the males and females respectively showing a slightly higher score for the males. The null hypothesis which states that there is no significant difference between male and female students' academic achievements in Integrated Science at JSCE is hereby accepted.

Question 5

Is there any significant difference between male and female students' academic achievements in Biology at SSCE?

Hypothesis 5

There is no significant difference between male and female students' academic achievements in Biology at SSCE.

Table 5: Independent t-test statistics of the male and female students' academic achievements in Biology at SSCE

\begin{tabular}{|l|l|l|l|l|l|l|l|l|}
\hline Variable & Gender & N & Mean & Std. dev. & Df & T-calculated & T-critical & P \\
\hline $\begin{array}{l}\text { SSCE } \\
\text { PERFORMANCE }\end{array}$ & MALE & 246 & 43.9715 & 6.89833 & 244 & 0.136 & 1.96 & $\mathbf{0 . 8 9 2}$ \\
\hline & FEMALE & 174 & 43.8736 & $\mathbf{7 . 7 4 9 4 1}$ & & & \\
\hline
\end{tabular}

Table 5 shows that the calculated $\mathrm{P}$ value of 0.892 is higher than 0.05 alpha level of significance and the $t$-calculated value of 0.136 is lower than the $t$-critical value of 1.96 . The mean performances of the male and female students at the SSCE are 43.972 and 43.874 respectively, again showing only a slightly higher performance of the males than the females. Therefore, the null hypothesis which states that there is no significant difference between the male and female students' academic achievements in Biology at SSCE is hereby accepted.

\section{Discussion Of Findings}

Table 1 reveals a significant relationship between overall students' academic achievements in Integrated Science at JSCE and Biology at SSCE in Soba LGA of Kaduna State, Nigeria. This means that a student who performs well in Integrated Science in likely also to perform well in Biology. Tables 2 and 3 further confirm the effectiveness of the prediction in Table 1. This means that students' achievements in Integrated Science significantly predict their achievements in Biology irrespective of the gender of the student i.e, a male or female student who performs well in Integrated Science is likely also to perform well in Biology. This tends to show that Integrated Science is still very relevant and students' achievements at JSS level is almost enough criterion in selection of students into the senior secondary school but unfortunately this is not strictly adhered to. As observed by Olatoye (2004), students' choice of career is more influenced by parents rather than the students' ability in the subject. 
The finding also shows that the achievement of students in JSCE is very important in their achievements in SSCE which is a pointer to the fact that it must be considered seriously if students' achievements in SSCE must be improved upon. It is no more news that the poor performance of senior secondary students in sciences including Biology has been persistent over the years. This generally poor achievements of students in SSCE have attracted comments and reactions from many stakeholders in education including government, law makers, parents and the public at large (Olatoye, 2004); Okpala, 2010; Lakpini and Atadoga, 2012; Alam et al., 2012; Dike and Salisu, 2015).

The finding of this research is in consonance with that of Oyedokun (1999) who reported that students' scores in Integrated Science predicted their latter achievement in Biology in Kontagora, Niger state, Nigeria. It is also in line with Osokoya (1999), Olatoye and Afuwape (2004), who reported that students' scores in Integrated Science not only predicted their later achievements in Biology but also in Chemistry and Physics. Internationally, Othion and Kishor (1994) found that the Kenyan certificate of primary education (CPE) had a moderate linear relationship with the Cambridge secondary certificate (CSE) examination grades. In developed countries such as the United states of America (USA), reports also show that students who are exposed to Integrated Science programme have significantly higher scores in science achievements showing a high predictive level (Turpin and Cage, 2004).

However Olowa (2009) opined that not all JSCE subjects have adequate predictive strength. The finding does not agree with Edokpayi and Suleiman (2011) who found that the academic achievements of students in JSCE among some selected schools in Zaria metropolis, Kaduna state, Nigeria, was a poor predictor of their latter achievements in Chemistry at SSCE. Afolabi and Adewolu (1998) and Adebayo (2002) also reported in their separate studies that student's JSCE achievements are poor predictor of their achievements at SSCE in Ekiti and Osun state, Nigeria respectively.

Tables 4 and 5 reveal that there is no significant difference between the achievements of male and female students' academic achievements in Integrated Science at JSCE and Biology at SSCE. This result is consistent with that of Olatoye and Afuwape (2004) who also reported that there was no significant difference between male and female students academic achievements in Integrated Science at JSCE and not only in Biology at SSCE but also Chemistry and Physics.

\section{Conclusion}

Based on the results obtained from this study, one important factor to be considered in the placement of science students irrespective of gender in the senior secondary schools should be their achievements in Integrated Science at JSCE. This is important because the students' over all achievements of the male and female students in Integrated Science significantly predict their later achievements in Biology at SSCE. This implies that a student irrespective of his or her gender who achieves well in Integrated Science is likely to perform well in Biology. This will enable schools to get good students to offer not only Biology but other science subjects thereby improving the performance of students at the SSCE.

The study also reveals that achievements of students at both the JSCE and SSCE show no gender disparity since male and female students' performances were at par at each of the examinations.

\section{Recommendations}

Based on the findings of this study, the following recommendations were made:

1. Career counselors should also consult students' past record in Integrated Science before advising them to offer science subjects including Biology.

2. Only competent and well qualified teachers should be employed to teach Integrated Science to enable students to have a solid foundation in sciences including Biology.

3. There should also be provision for well qualified teachers to teach the science subjects at the SSS level to improve the performance of students at SSCE.

4. Adequate facilities should be provided by the relevant authorities for the teaching of both the Integrated Science and all the science subjects in general.

\section{References}

[1]. Abdullahi, A. (1983). A study of predictive value of Joint Matriculation Examination (JME) in selected school subjects.Journal of Nigerian Educational Research Association, 3(1).

[2]. Adebayo, A. (2002). Predictive validity of the junior secondary school certificate examinations (JSCE) for academic performance in senior secondary school certificate examinations (SSCE) in Ekiti State, Nigeria.Unpublished M.Ed. Thesis, University of Ado-Ekiti, Nigeria pp. $60-62$.

[3]. Adebola, S.I. (2004). The relationship between students' performance in junior secondary mathematics, further mathematics and physics.Proceedings of the $45^{\text {th }}$ Annual Conference of Science Teachers Association of Nigeria (STAN).

[4]. Ademola, K.B. (2004). Students' performance in mathematics as correlates of their basic science subjects. Proceedings of the 45 Annual Conference of Science Teachers Association of Nigeria (STAN).

[5]. Afolabi, E.R and Adewolu, B.A Nigerian Journal of Social and Educational Research, 1: 35 - 42. 
[6]. Alimi, O.S., Ethinola, G.B and Alabi, F.O. (2012). School types, facilities and academic performance of students in senior secondary schools in Ondo state, Nigeria. International Education Studies, 5(3).http://dx.doi.org/10.5539/ies.v5n.3p44

[7]. Chen, J.F., Hsieh, H.N. and Do, Q.H (2014). Predicting student academic performance: A comparison of two Meta-Heuristic Algorithms Inspired by Cuckoo Birds for Training Neural Networks. www.mdpi.com/journals/alogrithmsdoi:10.3390/a7040538.

[8]. Dike, N.I. and Salisu, H. (2015). Inadequate laboratory facilities and utilization: Pedagogical hindrance to students' academic performance in Biology in senior secondary certificate examination in Zaria Metropolis, Kaduna state, Nigeria. Internal Business Research, 8(9), $124-134$

[9]. Dike, N.I. (2001). Students' senior school certificate examination grades as correlate of their academic performances in Science in the National Certificate of Education at the Federal College of Education, Zaria. Journal of Educational Studies (ZAJES), 7(1\&2): $116-122$.

[10]. Edokpayi, J.N. and Suleiman, M.A. (2011). Students integrated science achievement as predictor of later achievement in chemistry: A case study among selected secondary schools in Zaria Metropolis, Archives of Applied Science Research 3(4): 527 - 535.

[11]. Falaye, B.A and Afolabi, E.R.I. (2005).The predictive validity of Osun State Junior Secondary Certificate Examination. Electronic Journal of Research in Educational Psychology 5-3(1), 131-144.

[12]. Huang, S and Fang, N. (2013).Predicting student academic performance course: A comparison of four types of predictive mathematical models. www.science.direct.com $>$ article $>$ pii

[13]. Lakpini, M.A and Atadoga, M.M. (2012).Learning environment on senior secondary school students' academic performance in science in public secondary schools in Kaduna state. Proceedings of the $1^{\text {st }}$ African Forum of Teaching Regulatory Authority (AFTRA), 1,190-196.

[14]. Lawal, N., Badu, J.B. and Chukwuemeka, E.J. (2015).Predictive validity of first year GPA and final degree classification among Management and Social Science students. The International Journal of Science and Technology. Available @ www.theijst.com

[15]. McGrath, M. and Braunstein, A. (1997). The prediction of fresh men attrition: An examination the importance, financial and social factors. College Student Journal, 3(3), 396-408.

[16]. Nwanza, E.J (1993). The predictive of the Malawi school certificate examination for selection to the University of Malawi. A paper presented at the conference of the Association for Educational Assessment in Africa.

[17]. Okpala, P. (2010). Season of mass failure. The Nation, April, 2010.

[18]. Olatoye, R.A. and Afuwape, M.O. (2004). Students' integrated science achievement as a predictor of later achievement in Biology, Chemistry and Physics. Journal of Science Teachers Association of Nigeria(STAN), 39(1,2), 10 - 15.

[19]. Omirin, M.S. and Ale, V.M. (2008). Predictive validity of English and Mathematics mock examination results of senior secondary school students' performance in WASCE in Ekiti state, Nigeria. Pakistan Journal of Social Sciences, 592); $139-141$.

[20]. Othuon, L. and Kishor, N. (1994).Hierarchical linear modelling of predictive validity: The case of Kenya certificate of Primary Education Examination. Studies in Educational Evaluation, 20: 181-190.

[21]. Oyedokun, M.R. (1999). Students' performance in integrated science at junior secondary school as a predictor of achievement in Biology at senior secondary school level. Nigerian Journal of Research Education, $106-110$.

[22]. Turpin, T and Cage, B.N (2004). The Effect of integrated activity based science curriculum on students' achievement, science process skills and science attitudes. Electronic Journal of Literacy through Science, (3). 